\title{
表情筋トポグラフィーの開発と臨床応用
}

\author{
小幡 悦 朗
}

\section{Research in the Development of a Facial EMG \\ Topography System and Its Clinical Application}

\author{
Etsuro Obata \\ (Kagoshima University)
}

To evaluate total facial movement, the author developed color EMG mapping of the face (Face EMG Topogram) using a multi-practicable computerized topography system. During voluntary contractions of mimetic muscles, such as lifting the skin of the forehead, closing the eyes, pushing the eyes and blowing out the cheeks, 16 monopolar EMG are concurrently recorded from the surface of the face bilaterally: frontal, orbicularies oculi, orbicularis oris, etc. The data are fed to an on-line computer and integrated and calculated with interpolation formulae. To emphasize the activity of each recording area, the author used an 11-color computer-graphic display or an 11-plotiing-pattern display. These grades of display are considered to be related to the amcunt of muscular activity. The results obtained from normal subjects were reliable and reproducible. Next, the author applicd this system to patients with facial nerve paralysis and discussed the differences between the facial grading methods which depend on visual determination or topographic grading. In the topographic grading method the area ratio of the paralytic side to the normal side was calculated in each class ( $\mathrm{CO}$ to $\mathrm{CX}$ ).

The results showed little variation of each facial movement, but some significant differences were olitained between the methods of evaluation. The Face EMG Topogram was a precise, non-invasive objective technique of quantifying facial movements and facial palsy.

Key words: facia! movement, mimetic muscle, Face EMG Topogram, facial palsy

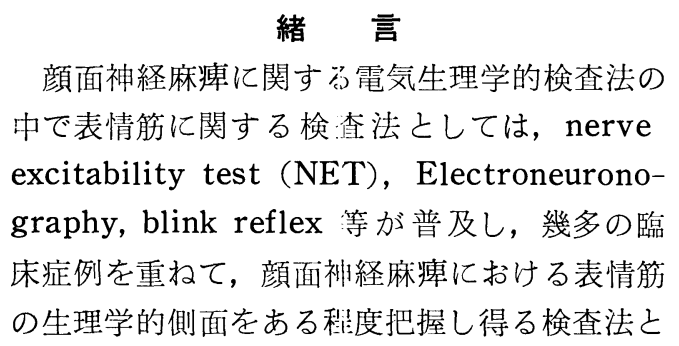

なっている、しかしながら, 顔面神経麻瘦の解 析に止まらず，広く表情運動障害を惹起する疾 患すべてを対象として, 表情運動の全貌を評価 し得る電気生理学的測定手法の開発に関しては 未だ報告を見ない，それは，表情運動が，多数 の表情筋の微妙な協同運動であり, $4 \mathrm{ch}$ 以下の 少チャンネルシステムの電気生理学的手法に頼 
る場合, 個々の表情筋の特定時の筋活動を解析 することはできても，その全体像を簡潔かつ， 忠実に把握することが困難であったためであ る.

生体の全体像を解析するシステムの開発は, 1970年代のコンピュータ時代に入り, 多チャン ネル記録の解析が瞬時に可能になってはじめて 着手されたと言っても過言ではない.なかで 屯臨床分野における CT-scan や magnetic resonance image (MRI) の出現は診断学の 分野において様々な変革をもたらしている。一 方, 四肢筋や大脳の活動電位についても, コン ピューターを利用した等電位図的解析の研究が 注目されつつある，従って，表情運動の全体像 の解析においてもコンピューターの持つ多変量 解析能を利用すれば個々の筋電位の詳細を直接 視覚汇訴える形で，表現，解析することも可能 となり得る.われわれは多チャンネル記録を 二次元画像表示するトポグラフィーシステム 500 (日本電気三栄社製) の多変量解析能に注目 し, 昭和57年以来, 表情筋全体の筋力を客観的 に評価するシステム“表情筋トポグラフィーシ ステム”の開発を手掛けてきた12213)4)516)。“ト ポグラフィー”とは，“地勢”または “地勢 図”の意味で使用されている，すなわち，ある 生理現象の全体像を総合的に再構成する際, 活 動電位または代表值などを等高線を用いて立体 的に表現する事を意味している．換言すれば, 著者が目指す表情筋トポグラムは，様々な表情 運動時の “表情筋筋力地図” に近い屯ので， そ の臨床応用面での有用性を検討するものであ る. その結果, 顔面神経麻㾝の程度の客観評価 を始めとして, 多様な表情運動の臨床診断手法 として極めて有用であることが判明した。現 在なお，システムの改良を重ねている段階では あるが, 本表情筋トポグラフィーシステムの開 発の経緯を述べるとともに，その臨床応用成績 について若干の考察を加えて報告する.

トポグラフィーシステムの概要

コンピューターによる画像診断機種の一つで
あるトポグラフィーシステム 500 は元来，主に 脳波, 誘発電位解析用として開発されたもので ある．従って，当初は本システムを利用して表 情筋トポグラムを作成し，表情運動の解析を試 みることにしたが，その後，大容量を有し，か つ, データ解析に汎用性の増したトポグラフィ ーシステム 700 が登場するにおよび，乙れを用 いて表情筋トポグラムに専用のプログラムを開 発すること在企図した。ここでは，まず，著者 の開発した表情筋トポグラムの概要を中心にこ れら両トポグラフィーシステムの特徵や開発経 緯について述べる。

1) トポグラフィーシステム 500 について

昭和56年に製品化されたトポグラフィーシス テム 500 は, 主に脳波の画像解析用に開発さ れたものである，専用ソフトは，通常の脳波 （ $\alpha$ 波， $\beta$ 波， $\theta$ 波， $\delta$ 波など）解析用之，誘発 電位解析用の 2 種類が使用されている．表情運
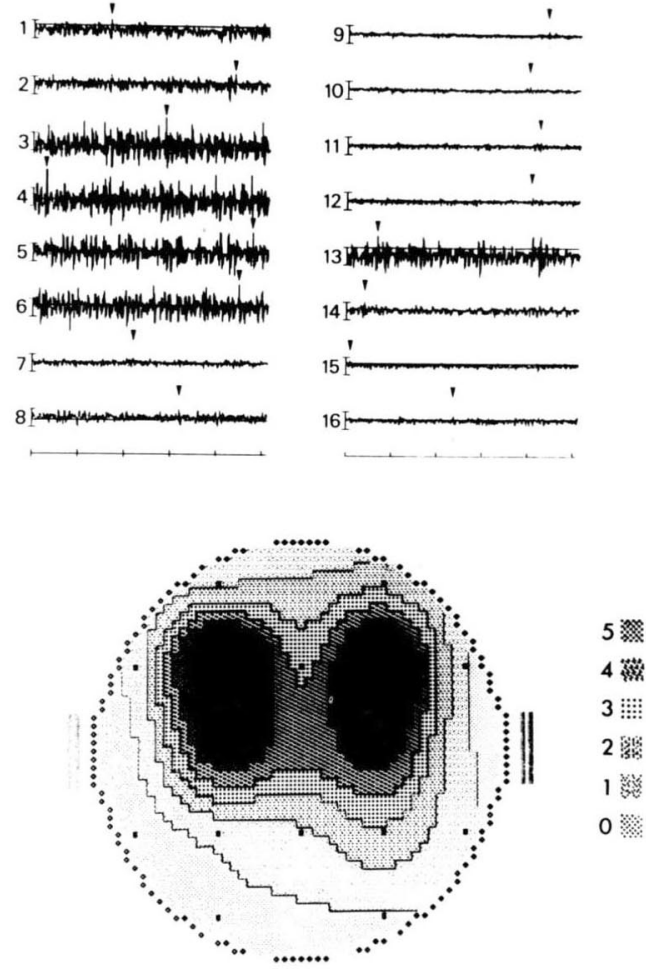

図 I“強い閉眼” 時のE MG 記録（上段）と表 情筋トポグラム表示 (下段) 
動の画像解析に着手した当初は，表情筋の随意 収縮時の自然放電の波形解析を行う目的で, 誘 発電位解析用のソフトを流用して，表情筋卜ポ グラムを作成することにした。

図 1 は強い閉眼を行った際の $16 \mathrm{ch}$ の筋電図 と AREA PEAK UP モード（ある任意の区 間における最大振幅值を各チャンネルの代表值 として選出）にて作成した表情筋トポグラムで ある. 筋電図上で矢印てて示した部位が ARE A PEAK UPモードにて選出された各 $\mathrm{ch}$ を 代表する peak である. 16ch すべてを判定材

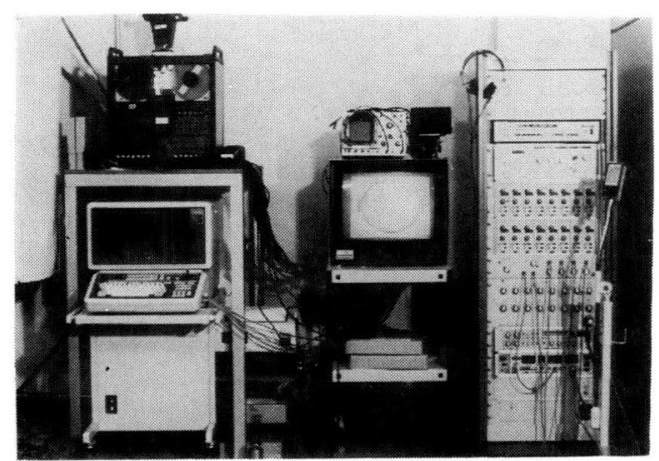

図 2 トポグラフィーシステム 700 の全容
料として扱う場合，筋電図そのものを一つ一つ 検討するととも可能ではあるが，かなりの繁雑 な作業を強いられる事になろう。従って，様々 な解析プログラムを用いて，それぞれの筋放電 の特徴（この場合は，記録時間内で最も高い振 幅）のみを抽出し, analogue data 以外の把 握しやすい表示法で再構成することが重要とな る. 図 1 で示した表情筋トポグラムは, 最も活 発な筋放電を示した両側の眼輪筋部が濃い赤 色（図においては濃い暗色で示されている部 分）にて提示され，左右の対称性む含めて実際 の表情を良く捉らえた表示法であることが示さ れている，また，表情運動の全体像を理解する という意味においても視認性に富む表示法であ るととがわかる.

トポグラフィーシステム 500 では，トポグラ ムそのものを32画面保管することができる． 32 画面の範囲内であれば，表情運動の解析を迅速 に行なうことができる（EMGのデータは保存 できない). また, 専用のポラロイドカメラに てカルテ添付用に撮影した後, 次の解析へと進

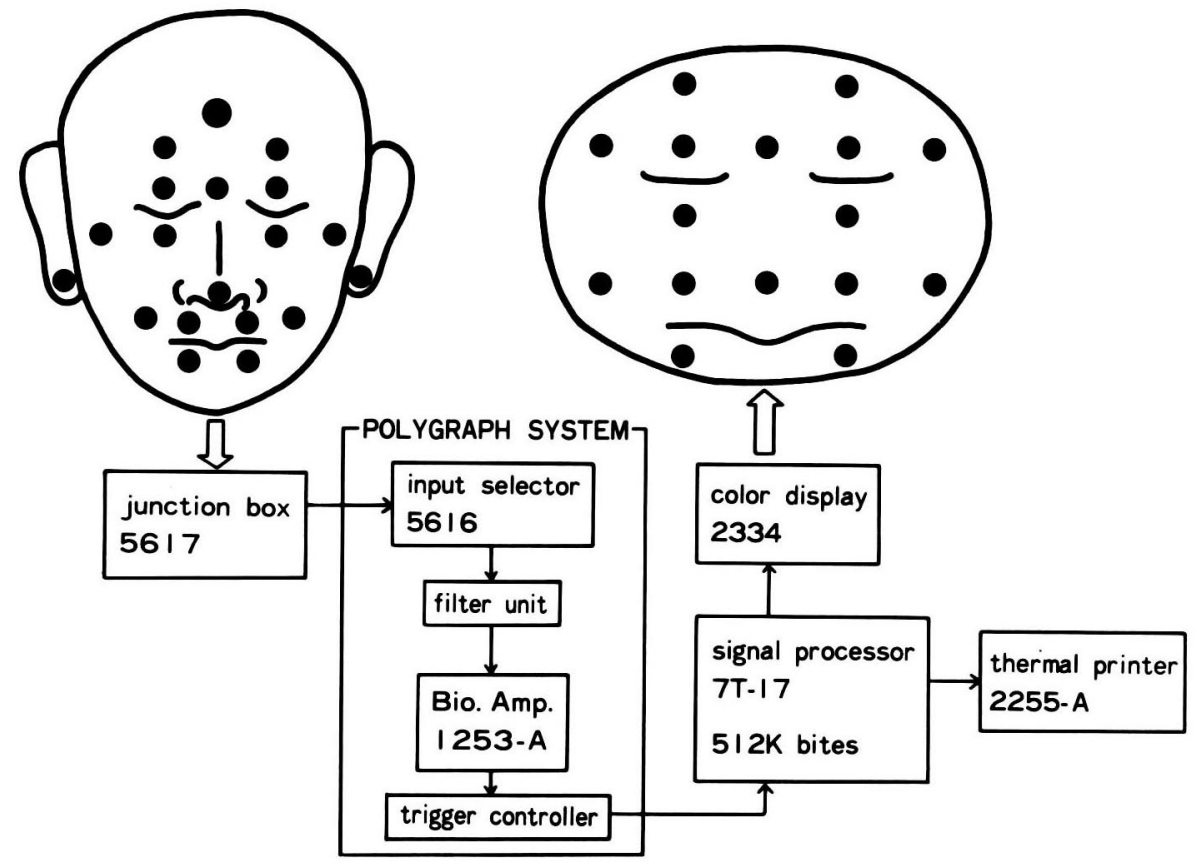

図 3 トポグラフィーシステム 700 のブロックダイヤグラム 
むととあ可能である.

トポグラフィーシステム 500 が改良されて, 次代世であるトポグラフィーシステム 700 が登 場したのは昭和58年である．本システムの導入 を契機に，誘発脳波解析用のプログラムを流用 することなく，より操作性の優れたシステムの 利用を目指して, 表情筋卜ポグラム解析専用プ ログラムの開発に着手した。

トポグラフィーシステム 500 における主な改 良すべき点としては，下記の項目が挙げられ る.

1. 最大振幅值を基本值にしているため,デ ータの再現性に問題がある.

2. EMGなよ゙の analogue data そのもの は保存できない.

3. 電源 off にて保存したトポグラム白体 が消去されてしまう。

4. 顔面痙攣の解析などに有用な連続記録が できない。

5. CRT上には $4 \mathrm{ch}$ 分の筋電図しか表示 できないため, 測定時の artifact チェック終 了まで時間を要する。

6. 頭部を真上から見た構図となっているた め左右の表示が逆になっている.

7. 顔面神経麻瘏症例の解析において左右高 の定量的解析機能がない，等々である.

2) トポグラフィーシステム 700 について

トポグラフィーシステム 700 は signal processor 7T-17 (容量512 kbyte) を中心に棈成 されている（図 2 がそのシステムの全容であ る). トポグラフィーシステム 700 のブロック ダイアグラムは図 3 に示す通りである. トポグ ラフィーシステム 500 との最む大きな相違点は 1. 8 inch floppy disket $に$ analogue data そ のむのを保存できること，2.16ch 同侍に signal processor 7T-17の C R T 上に表示でき, artifactのチェックが容易に行なえること，等 である。

以上の 2 点は signal processor $7 \mathrm{~T}-17$ 自 体が有する特徴でああるが，本システムをより
効果的に活用していくために，トポグラフィー システム 500 の久点を踏まえた表情運動解析専. 用プログラムを作製することが課題であった。 最屯重要な各 $\mathrm{ch}$ の代表值は, 比較的変動し 易い最大振幅值の代りに, 得られた筋電図を C RT上である任意の区間を integrate する ことによって得られる積分筋電図の值とした (sweep time は $512 \mathrm{msec}$ ). 積分值在得る方 法としては, R C 回路をシステム内に組み込 む方法と，CRT上で処理するととによって integrate する少法の二つがある. 前者はD C に近い形で波形が得られるため, sampling clock を延長でき，1画而上にて行なう F F T 解析においても比較的長時間の解析ができる利 点があるが，原波形の artifact の混入をチェ ックできない。したがって, 今回は, 得られた EMGをCRT上で integrate する方法を採
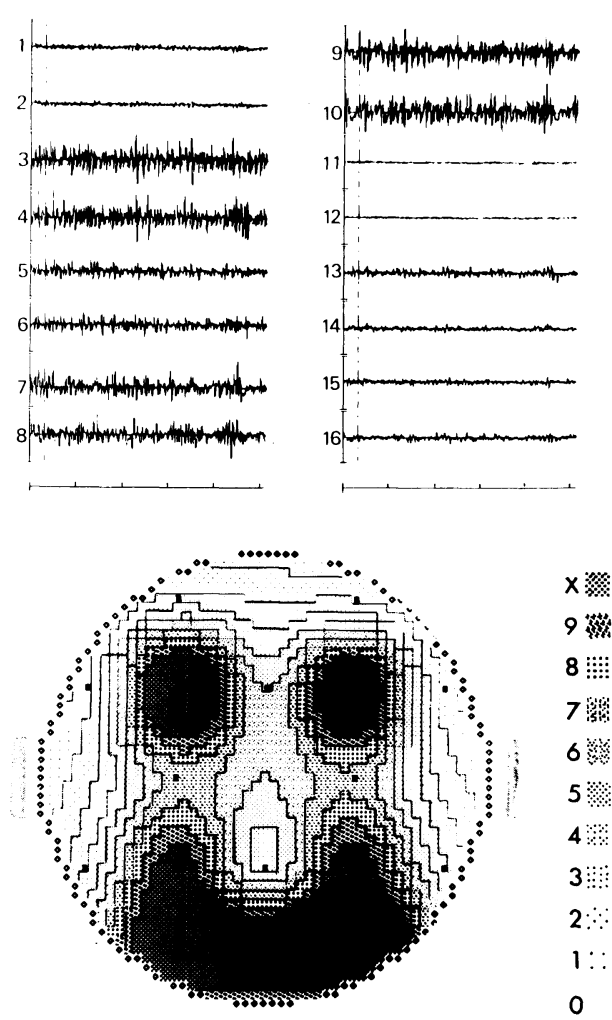

図 4 “しかめ面”（正常人）時の E MG 記録 （上段）と表情筋卜ポグラム表示（下段） 
用することにした.

トポグラフィーシステム 500 でのトポグラム 表示は暖色系のみの 6 段階で行なっているが, 本システムのカラー表示機能としては濃い青 色 (C 0 ) を最低值, 濃い赤色 (CX) を最高 值として寒色系から暖色系へと11段階（C 0 , $\mathrm{C} 1, \mathrm{C} 2, \mathrm{C} 3, \mathrm{C} 4, \mathrm{C} 5, \mathrm{C} 6, \mathrm{C} 7, \mathrm{C} 8, \mathrm{C} 9$, CX）でトポグラム表示する機能を有してお り, 新方式に移行するに際して11段階のカラー 表示を行なうこととした。また，カラ一画像表 示のみならず，様々なパターンを用いたモノク ロ表示機能をも備えている. とのパターン表示
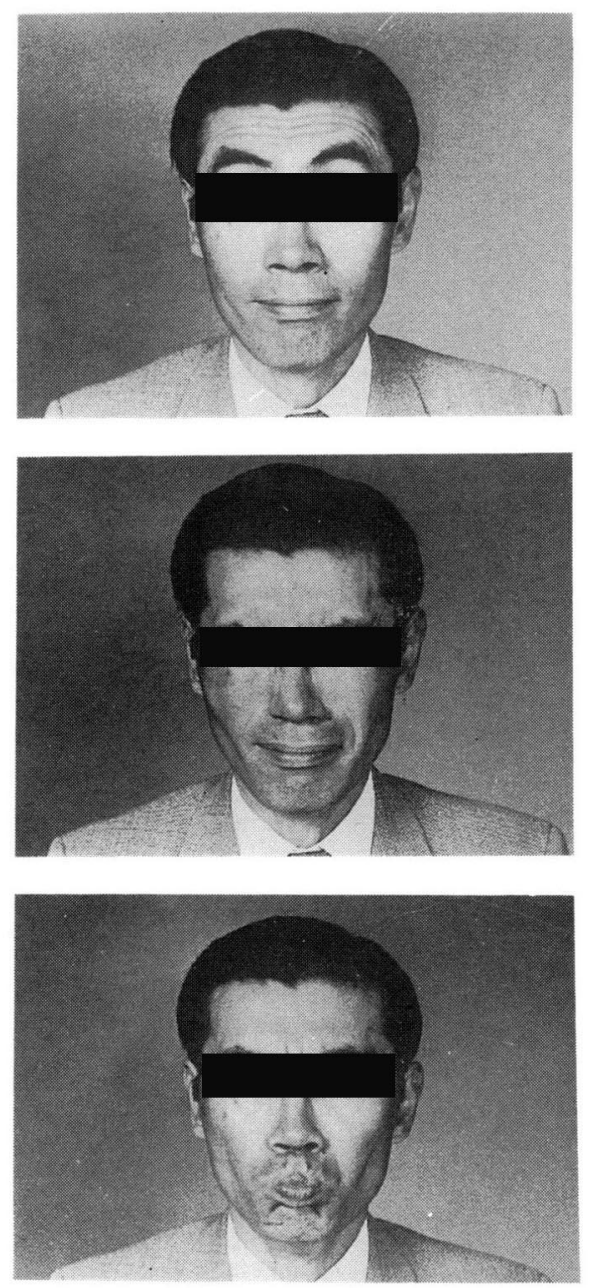

図 5 正常成人記録例

上段より, “前額作貱”，“強い閉眼”，“煩部臌満”の実際の表情と表情筋トポグラムを示す. ターン表示によるトポグラムを採用した. れる左右差の定量的判定は, トポグラムの視認 性に基づいた解析法として, 得られたトポグラ ムをC RT上にて縦の正中で二分し，各 step ごとに左右の面積比を算出し，\%表示によって 折れ線グラフまたは一覧表として画像表示する こととした.
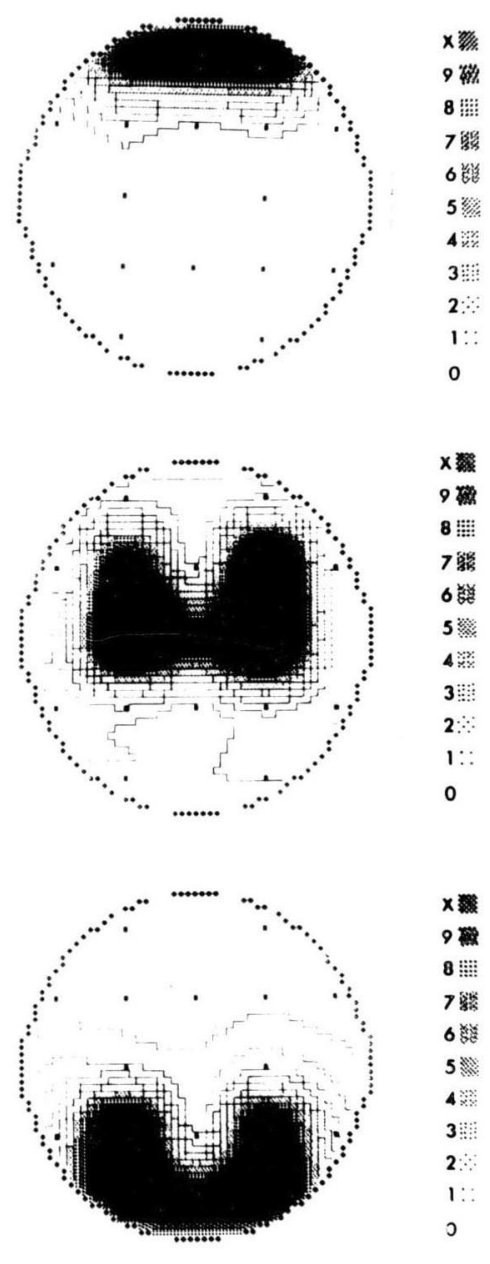

は, トポグラムのファイルに極めて有用であ り，本論文における図に関しては，全ててのパ

顔面神経麻瘴の程度判定において有用と思わ

図4 亿“しかめ面”をおこなった際の $16 \mathrm{ch}$ EMG 記録とそのトポグラムを表している. 筋 
放電のパターンは細かい区間で比較すると左右 異なった部分屯認められるが， $512 \mathrm{msec}$ 全体 にわたって積分した值を基にトポグラム表示す ると，両側上眼瞼部，口輪筋部がほぼ左右対称 亿最も濃い色彩パターンにて示され，かつ, 11 段階表示によって，より繊細な変化をむ解読で きるようになっている。

図 5 は，正常人に抢ける代表的な表情運動時 のトポグラム成績を示している．前額部作貱， 強い閉眼, 煩部膨満の 3 表情についての解析結 果であるが，それぞれ前頭筋部，眼輪筋部，口 輪筋部を中心に最も濃い色彩パターンで示さ れ，活発な筋放電の存在部位を的確に表した表 示結果であることがうかがえる，また，同一被 検者の “しかめ面”記録例を折れ線グラフ表示 にて左右差を解析した結果が図 6 である．C R T上でカーソルを操作することによって 512 msec の筋電図を 1 区画 $100 \mathrm{msec}$ ずつ 6 区画

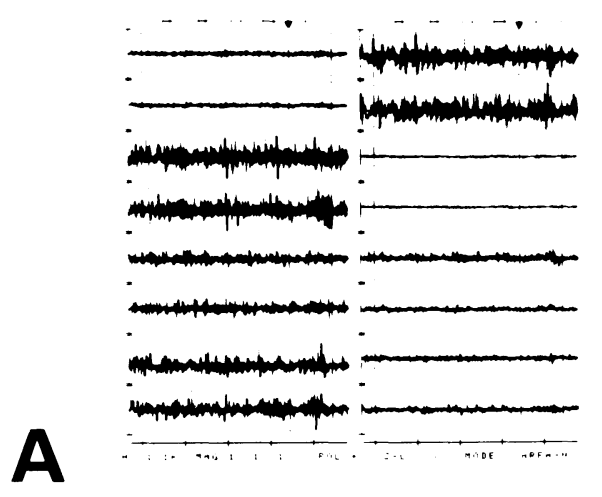

$\mathrm{T} 1$

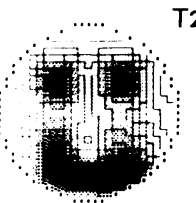

T4

2

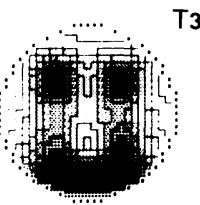

T5
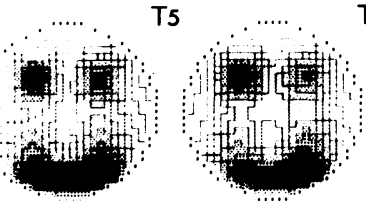

T3

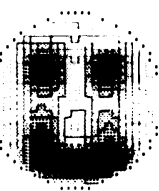

T6

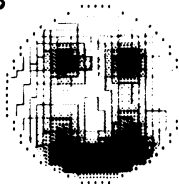

B

図6 A：16 ch。EMG表示

C : 左右面積比折れ線グラフ表示 (C 1 C C 4)
（最高10区画に分割可）に分割し，それぞれの 区画内を積分することによって得られる值を基 にして, 図 4 , 図 5 において示したトポグラム を縮小した形で 6 個の表情筋トポグラム（図 6 B）として作成するてとも可能である. 図 6 右

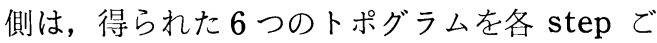
とに面積比を算出し，C 0 から CXまでについ $\tau \mathrm{R} / \mathrm{R}+\mathrm{L} \times 100$ (一つの class の全体の面積 分の右側の面積）の計算式にて，折線グラフ としてパーセント表示したあのである（折机線 グラフ表示は最高 4 class 分まで同一グラフ上 に表示できる). 6 分割表示したトポグラムに は僅かながら変動が認められる。C 1 からC 4 (図6 C), C 5 加 C 8 (図6 D) 沉ついて左 右差解析を行った成績においては，C1 から C 4 のグラフでは全く変動は見られず，C 5 か らC 8 の折机線グラフ表示に 6 分割表示トポグ ラムの変動が表れているととがわかる。しかし
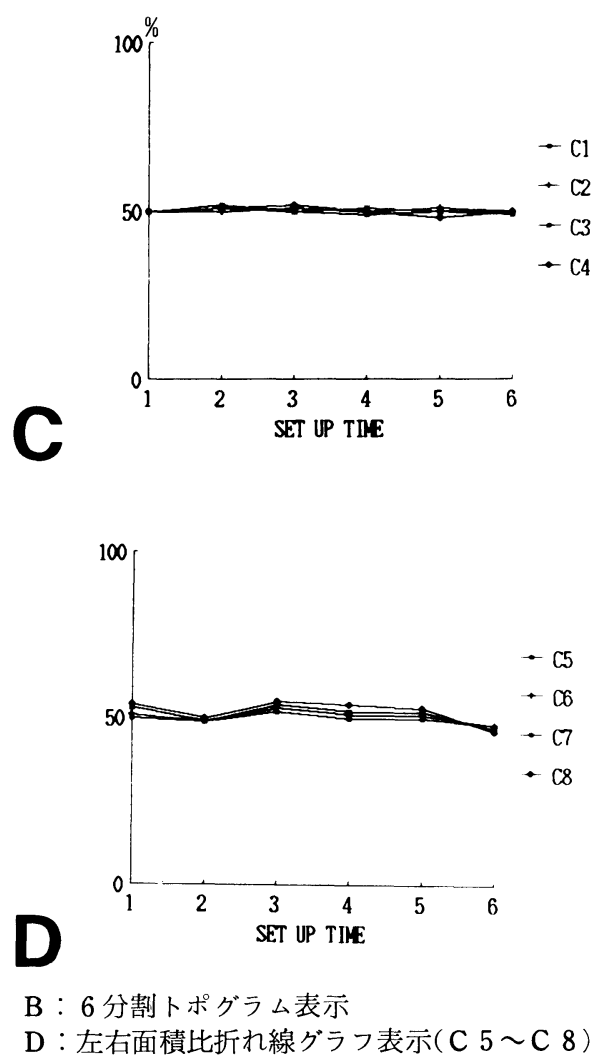
ながら,この変動は極めて振幅の小さなもの で, この“しかめ面”が, 左右対称な表情運動 であることを客観的に示した成績と言えよう。

3 ) 小括

脳波の解析プログラムを利用して開発した表 情筋トポグラムのシステムの目的と，乙れまで の変遷について，その概要を記した，それらを 要約すると,

A. 当初は, signal processor 7T-08 中心としたトポグラフィーシステム 500 を用い て誘発脳波解析プログラムを利用することによ って表情運動のトポグラム解析を試みることに した.しかしながら，本システムは，各 ch の筋電図の最大振幅値をその基本值にしている ため, 6 段階表示という粗なトポグラム表示で はあるが, 解結析果が変動し易い傾向が見られ た. データの保存に関してもトポグラムのみを ポラロイド写真として保存し得るに過ぎず, 意 図する時に筋電図を再解析する機能は具備して
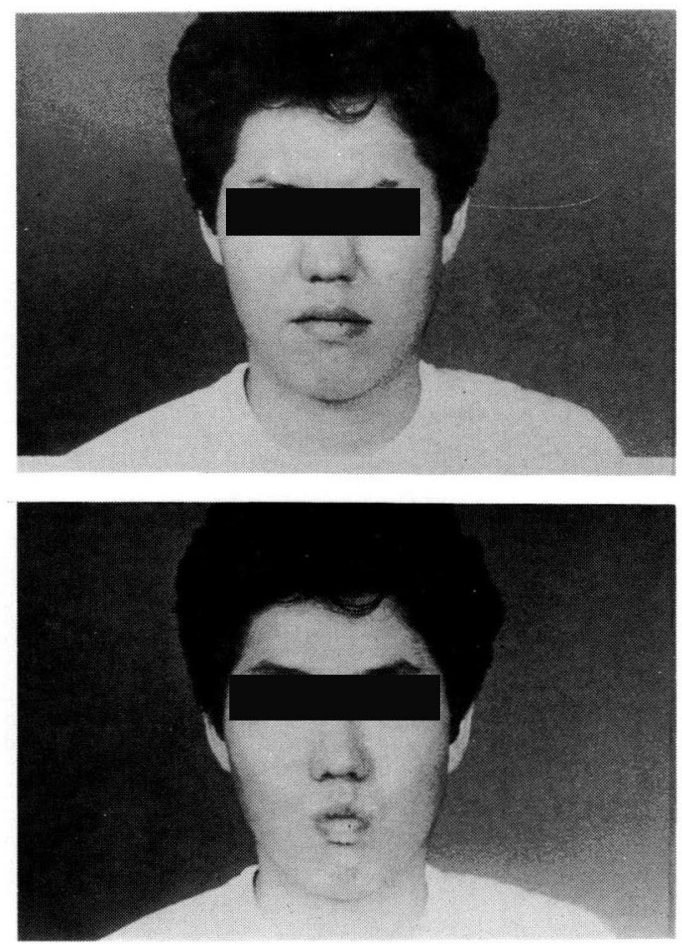

图 7 右顔面神経麻㾇患者（20才，男性）における “強い閉眼”（上段）之 “「ウー」の表情” (下段) の表情筋トポグラム表示結果

いない.

B. 次の段階では, signal processor 7T17を中心としたトポグラフィーシステム 700 に おいて表情運動の専用解析プログラムを作成し た. 筋電図を C R T 上で積分した值を基本值と し，11段階表示するとととした。そして，トポ グラムの視認性に基づく表情運動の左右差を解 析する方策として各 class ごとに左右の面積 比を算出し, 折れ線グラフ表示する機能を新た に加えた. 11段階の細かいトポグラム表示なが らトポグラム作成時の再現性は飛躍的に改善さ れ，また, analogue data の保管が可能なた め, 過去のデータを比較検討する際, 有用とな った．表情筋の臨床診断に関する新しい手法と

して十分活用可能なととが証明された.

\section{顔面神経麻舫症例における表情筋 トポグラム解析に関する研究}

表情筋トポグラムの臨床応用については, 広 く表情運動に何らかの障害を来す疾患を対象之
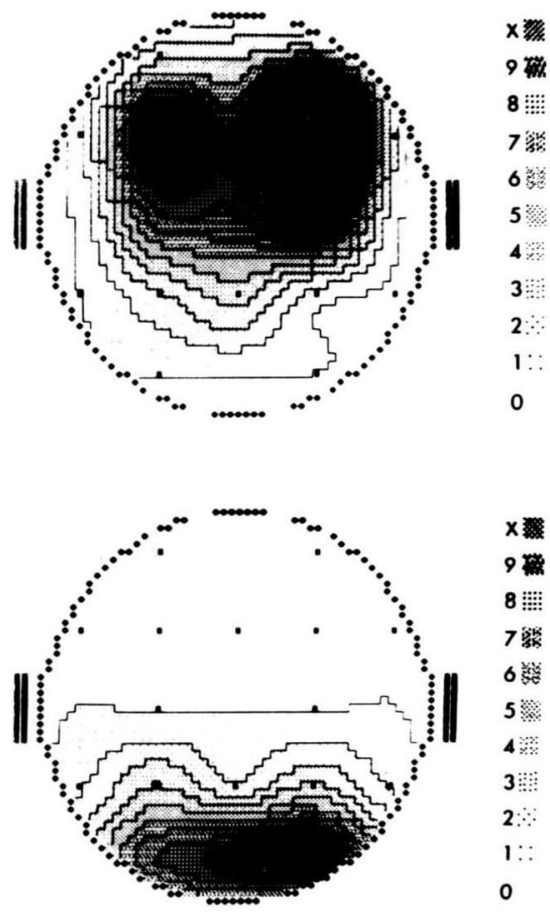
して, 著者は過去数年間にいくつかの具体例 （末梢性顔面神経麻瘏, 顔面痤尜, 重症筋無力 症など）を報告している．本章では，1984年， 4 月より 2 年間にトポグラム解析を行った末梢 性一側性顔面神経麻盘について，トポグラムに よる左右差判定と日本顔面神経研究会で一応容 鿄されている肉哏的麻瘏評価法（0 点， 2 点, 4 点の 3 段階評価法）とを比較検討した成績を 中心に示すととにする.

図 7 は, 受傷から28日目で, 治癒に近い状態 を示している外傷性顔面神経麻瘦（20才，男 性）症例の “強い閉眼”（上段）と“「ウー」の 表情”（下段）の実際の表情とトポグラム表示 結果とを対比して示したあのである. “強い閉 眼”に打いては肉眼的にも左右差を認めうる が，“「ウー」の表情”に打いては判然としな い.しかしながら，トポグラム上は, 明確にそ の左右差が提示されている，すなわち，“強い
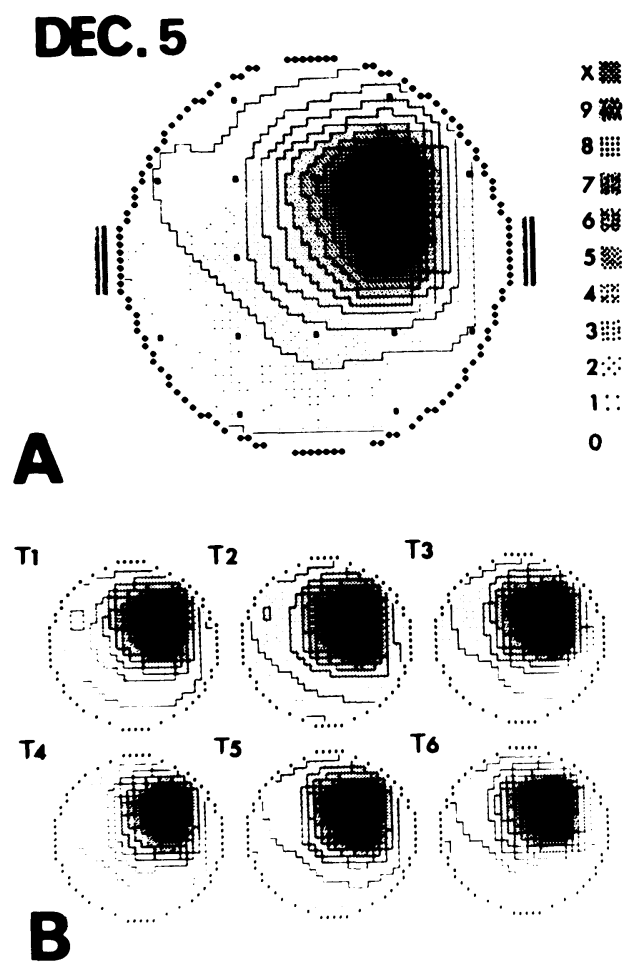

図 8 右ベル麻㾇患者（16才，男性）の表情筋トポグラム表示による経時的推移
A, B：1984年12月 5 日の記録
C, D：1984年12月12日の記録

TI

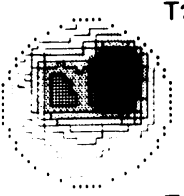

T4

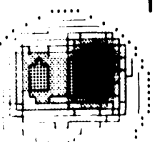

T5
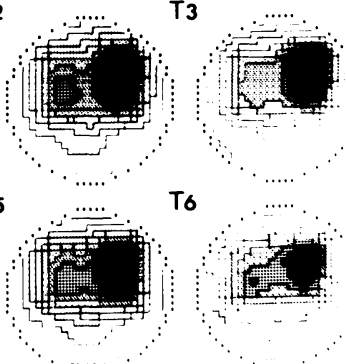

T6

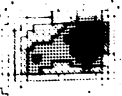

\section{D}

閉眼”（上段）においては，右下眼瞼部の筋力 回復が十分でなく，また，“「ウー」の表情” （下段）では，右下口唇部における值が低いこ とがトポグラム表示にて客観的に判定できる. この儖床例からは, 肉眼的評価法とトポグラム 走結果とが必ずしも一致せず，視認性に優れ るトポグラム表示の場合，回復の十分でない部 位を的確に表現し，かつ，肉眼的評価法に比 し，麻㯅程度を強調して提示することが可能な 表現方式であることが窅われる.

図 8-A, B, C, D は右ベル麻痺患者の“強 い閉眼” 時の, トポグラム的にみた回復過程を 健常側の最年筋放電の強い部分, 即ち, 左眼輪 筋部の濃い表示領域を一定にして示したもので ある. 麻瘦発症時10日目のA，Bの成績では麻 盘側である右眼輪筋部にはほとんど筋放電がな く，著しい左右差を示している，その 1 週間後 のC，Dの成績では右眼輪筋部は上下ともに等

\section{DEC. 12}

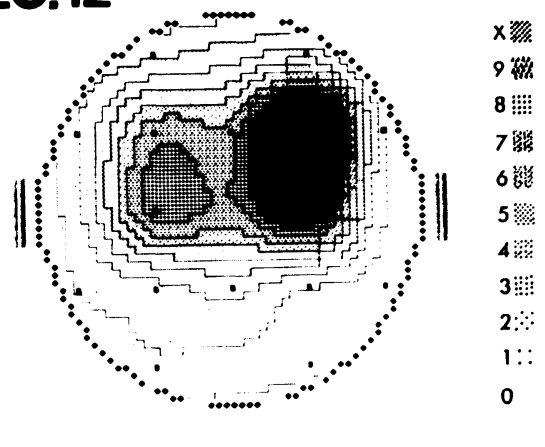


しい回復を示し，C 9 の class までトポグラ ム上に出現し，一見してかなりの改善が得られ ていることがわかる。また， B，Dの 6 連続卜 ポグラム表示は, それぞれ 1 sweep の E MG 上で， $100 \mathrm{msec}$ ごとに 6 区間を任意に選出 して構成したものである.上段に示した 512 msec すべてを基本値とした一画面表示のトポ グラムとも同様の構成になっており, かつ, 細 かい分画の表示にもかかわらず，個々のトポグ ラム間の動摇が少なく, 積分 $\mathrm{EMG}$ 值を基本と して表示する本方式が再現性に優れていること を臨床例においても示した成績である.

図一 $9 \mathrm{~A}, \mathrm{~B}, \mathrm{C}, \mathrm{D}$ は図 8 で示した 6 連続卜 ポグラム(Topogram 1 から Topogram 6) に おける左右差を本表示法のもう一つの特徴であ る折れ線グラフ表示で示したものである。 上段
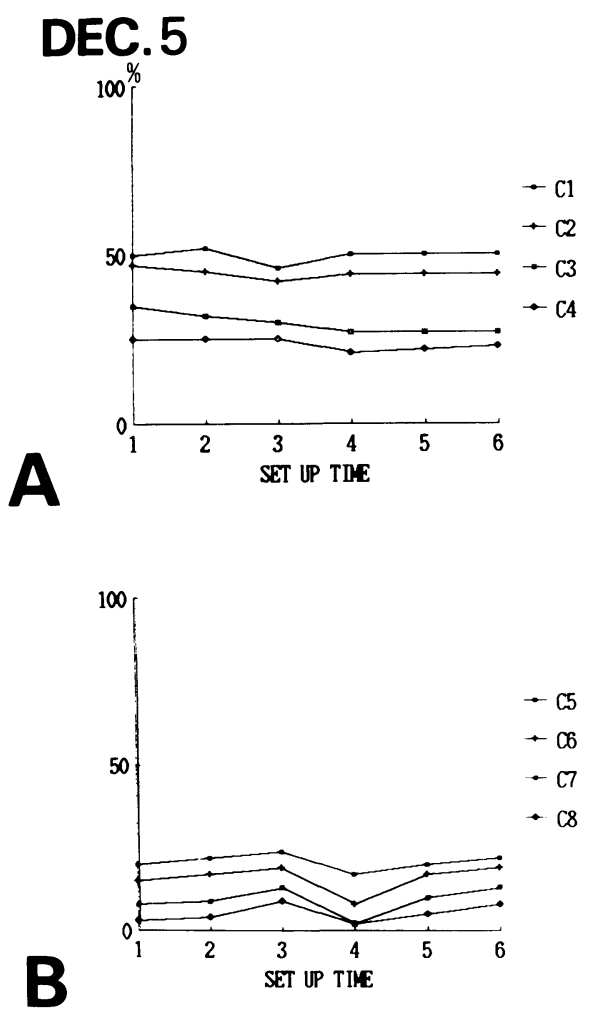

$\mathrm{A}, \mathrm{C}$ がC $1, \mathrm{C} 2, \mathrm{C} 3, \mathrm{C} 4$ を，下段 B， D が C 5, C 6, C 7,C 8 の各 step について Topogram 1 から Topogram 6 亿対応して $\mathrm{R} / \mathrm{R}+\mathrm{L}$ の\%表示を行っている. 上段 $\mathrm{A} ， \mathrm{C}$ においてはともに35〜 50\%の間を推移し両者間 にさほどの差は示されていないが，下段 B，D ではC 5 〜 C 7 までが $30 \%$ 以上の安定した高值 を示すようになり，C 8 のみが 5 〜35\%の間を 大きな変動を示しながら推移しているととがわ かる，このことから，麻痺の回復程度に応じて ある class までは安定した值をとるととが示 され，具体的にトポグラム上のどの class が 肉眼的麻痷評価法とどの程度の対応を示してい るか沉ついての検討が必要之なる.

$\mathrm{C} 4, \mathrm{C} 5, \mathrm{C} 6, \mathrm{C} 7, \mathrm{C} 8, \mathrm{C} 9, \mathrm{CX} \mathrm{R}$ : $\mathrm{L}$ （主な筋放電部位の積分 $\mathrm{EMG}$ 值の比）の 8
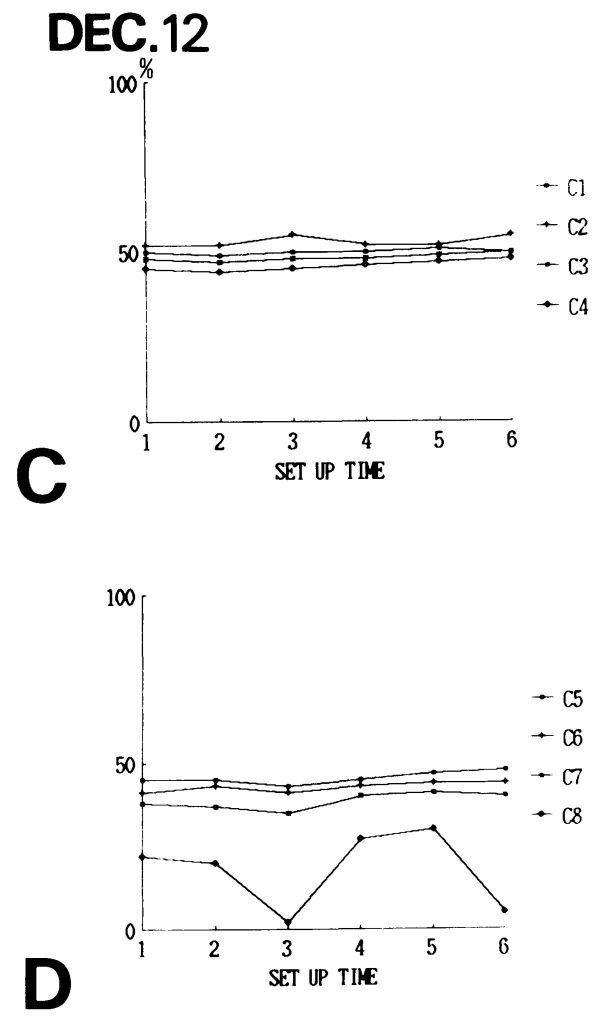

図 9 図 8 亿示した症例の折れ線グラフ表示による左右差解析

$\mathrm{A}: 12$ 月 5 日のC $1, \mathrm{C} 2, \mathrm{C} 3, \mathrm{C} 4$ の成績, B : 12月 5 日のC $5, \mathrm{C} 6, \mathrm{C} 7, \mathrm{C} 8$ の成績 $\mathrm{C}: 12$ 月12日のC $1, \mathrm{C} 2, \mathrm{C} 3, \mathrm{C} 4$ の成績, D : 12月12日のC $5, \mathrm{C} 6, \mathrm{C} 7, \mathrm{C} 8$ の成績 
項目についてその百分率と 0 点, 2 点, 4 点の 3 段階による肉眼的麻瘏評価法との関係につい て検討した結果を図10から図13に示す。

図10は，“前額部作貱”における成績である. 解析総症例数は29例で, それらの肉眼的麻瘏評 価法による分類の内訳は， 0 点群が 8 例， 2 点 群12例， 4 点群は 9 例である. $\mathrm{R}$ ：Lは前額部 左右一箇所の記録電極の積分 EMG 值より林痺 側/健常側の比をとって算出したものである. 各 class ごとの 0 点， 2 点，4点に対する百 分率評価を左側に，個々のグラフの全体的傾向 を検討するために一つにまとめたグラフを右側 に示した．各 class ごとの肉眼的評価法との 相関関係を検討した結果， C 4,C 5 の 2 つの class とR：Lに执いては 3 群間に $1 \%$ の危険 率で，また，C 6 とC 7 においては 1 〜 $\%$ の 危険率で肉腿的評価法と一致した判定が行われ ていることがわかった. 全体的傾向としては, 2 点に対するトポグラム解析症例においてC 4
からC 7 間の各 class 間で比較的安定した槽 準偏差をむって class が高い程一定間隔を置 いて低值を示す傾向が認められるものの，他の 症例群においては, 慒準偏差值伒なりの開き が認められ，一定の傾问を見出すことは困難で ある.

図11は, “強い閉眼”例における解析結果を 示したあのである。総症例数 29 例であり, う ち, 肉眼的铎価 0 点の症例が10例, 2 点の症例 が11例， 4 点の症例が 8 例であった。本解析の 際の R：Lは両側眼輪筋部の上下に貼付した 4 個の電極においてそれぞれの積分 EMG值の左. 右比を平均して算出したものである. 左側の class 別解析結果では， C 7 と R：Lにおい て, 肉腿的評価法にて分類した 3 つの群相互に 対して $1 \%$ 危険率で有意差が認められた。 ま た, C 6 では 0 点群と 2 点群間が $1 \%, 2$ 点群 と 4 点群間が $5 \%$ の危険率で有意差を示してお り，C 8 ではその逆の関係になっている，全体

\section{Lift skin of forehead}

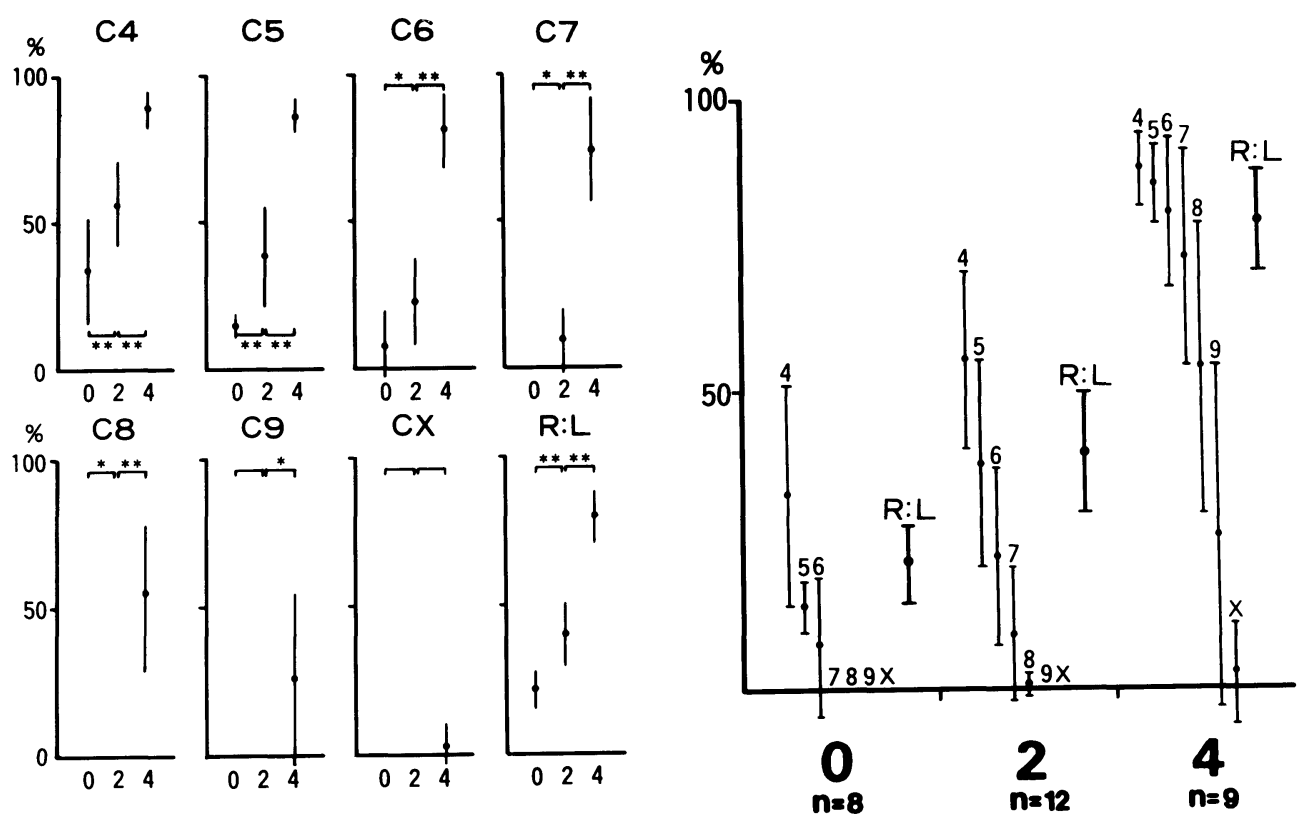

図10 “前額作貱”症例における表情紛トボグラムの左右差解析と 3 段階 肉眼的麻痺評価法との比較成績 
のまとめにおいては，2 点群において同様な槽 準偏差をむって，class が上がるにつれその平 均値が一定の傾向をもって低值へと推移してい ることが示されている，また，解析した症例の なかで 4 点群の C Xが最む大きく変動している ことあ指摘される.

図12は, “「ウー」の表情”例の解析結果であ る. 肉眼的な評価 0 点群が 8 例, 2 点群が 14 例, 4 点群が 11 例, 総症例数は33例である. 各 群間で $1 \%$ の危険率をむって有意差が認められ た class はC 4 のみであった。 また，本表情 運動においても $\mathrm{R} ： \mathrm{~L}$ は, 同じく，1\%の危険 率で 3 群間に有意差が認められた。ささに, C 5, C 6, C 7 の class では 0 点群〜 2 点群 間，または， 2 点群〜 4 点群間において $1 \%$, ないしは $5 \%$ の危険率で有意差を認めた。な お， $\mathrm{R}: \mathrm{L}$ は口輪筋部の左右の上方下方に貼付 した 4 個の電極においてそれぞれの積分 $\mathrm{E} M \mathrm{MG}$ 值の左右比を平均して算出したものである. 全
体的傾向としては，4点群において標準偏差， 平均值に動摇が認められるが, 0 点群と 2 点群 とにおいては，標準偏差ならびに平均值ともに 一定の傾向を有している。

図13は，“煩部膨満”例における成績である. 0 点群が 7 例, 2 点群が 8 例, 4 点群が 7 例, 総症例数は 22 例である. 解析症例数は少ないな がら，C 4, C 5, C 6, R : L において $1 \%$ の 危険率を屯って 3 群間に有意差が認められた。 本解析にお汀る R：Lは, “「ウー」の表情”之 同様に口輪筋周囲の 4 電極の積分值より算出し た. また, 全体的傾向として 0 点群の C $9, \mathrm{C}$ $\mathrm{X}, 4$ 点群の C $4, \mathrm{CX}$ を除けば平均值, 標準 偏差ともに安定した值を示していることがうか がえる.

\section{考察}

コンピュータ技術の隆盛に伴い, 各種の画像 診断器が輩出し, 従来では想像の域を出なかっ た生体内の様々な情報を捉らえる事が可能とな

\section{Close eyes}
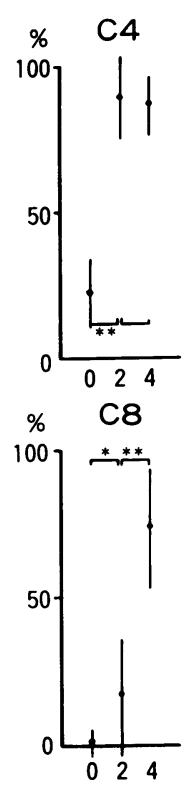

C5

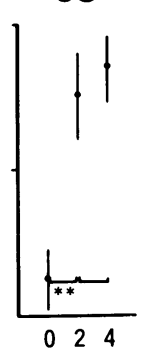

C9

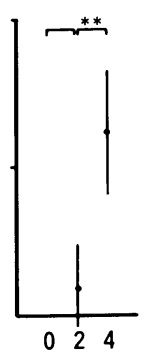

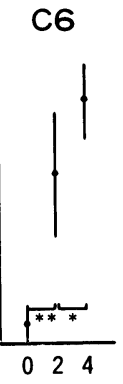

CX

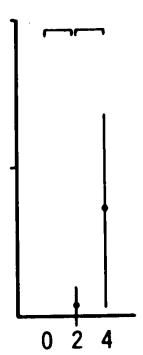

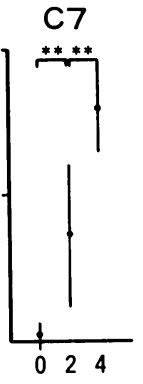

$\mathrm{R}: \mathrm{L}$

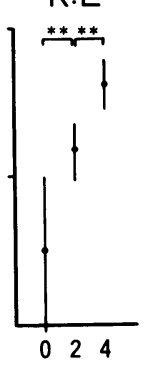

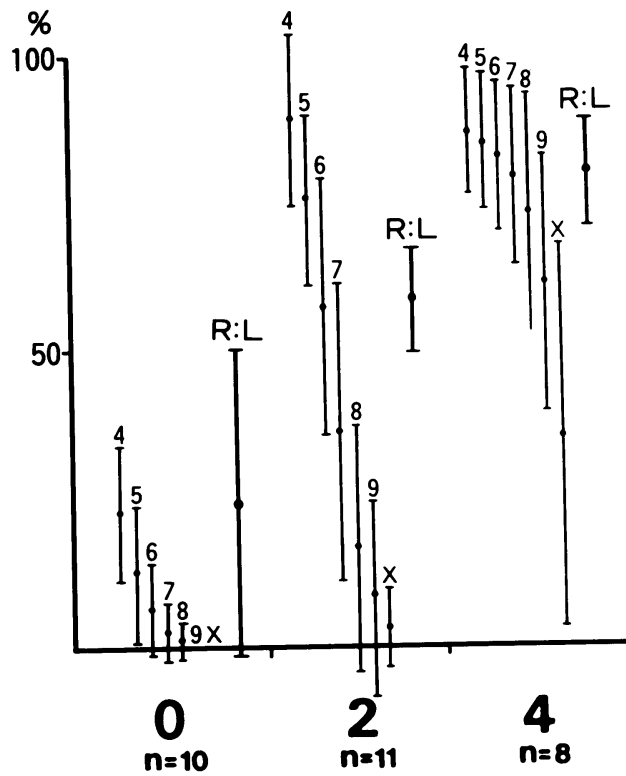

図１I“強い閉眼” 症例における表情筋トポグラムの左右差解析と 3 段階 肉眼的麻䠋評価法との比較成績 


\section{Point mouth}

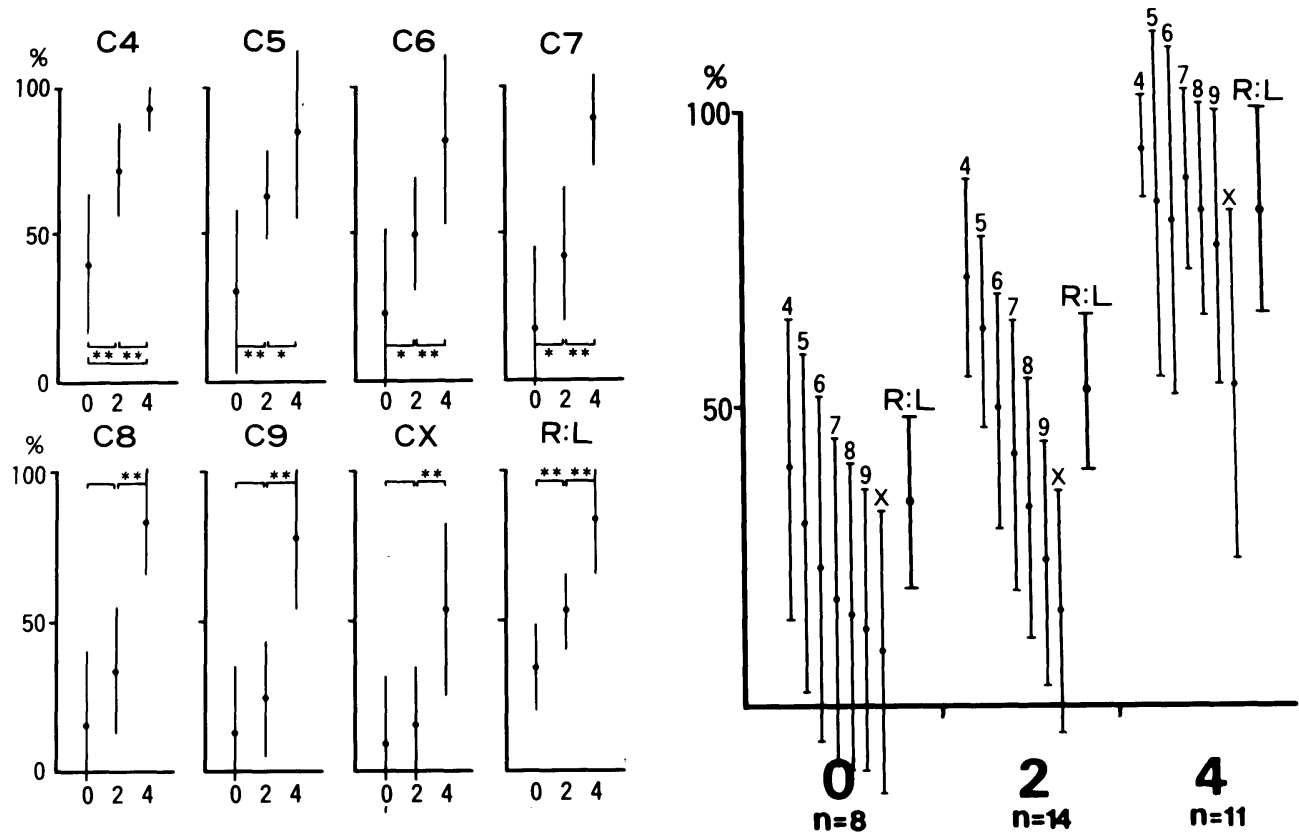

図12 “「ウー」の表情” 症例における表情筋トポグラムの左右差解析と

3 段階肉眼的麻瘏評価法との比較成績

\section{Blow out cheeks}
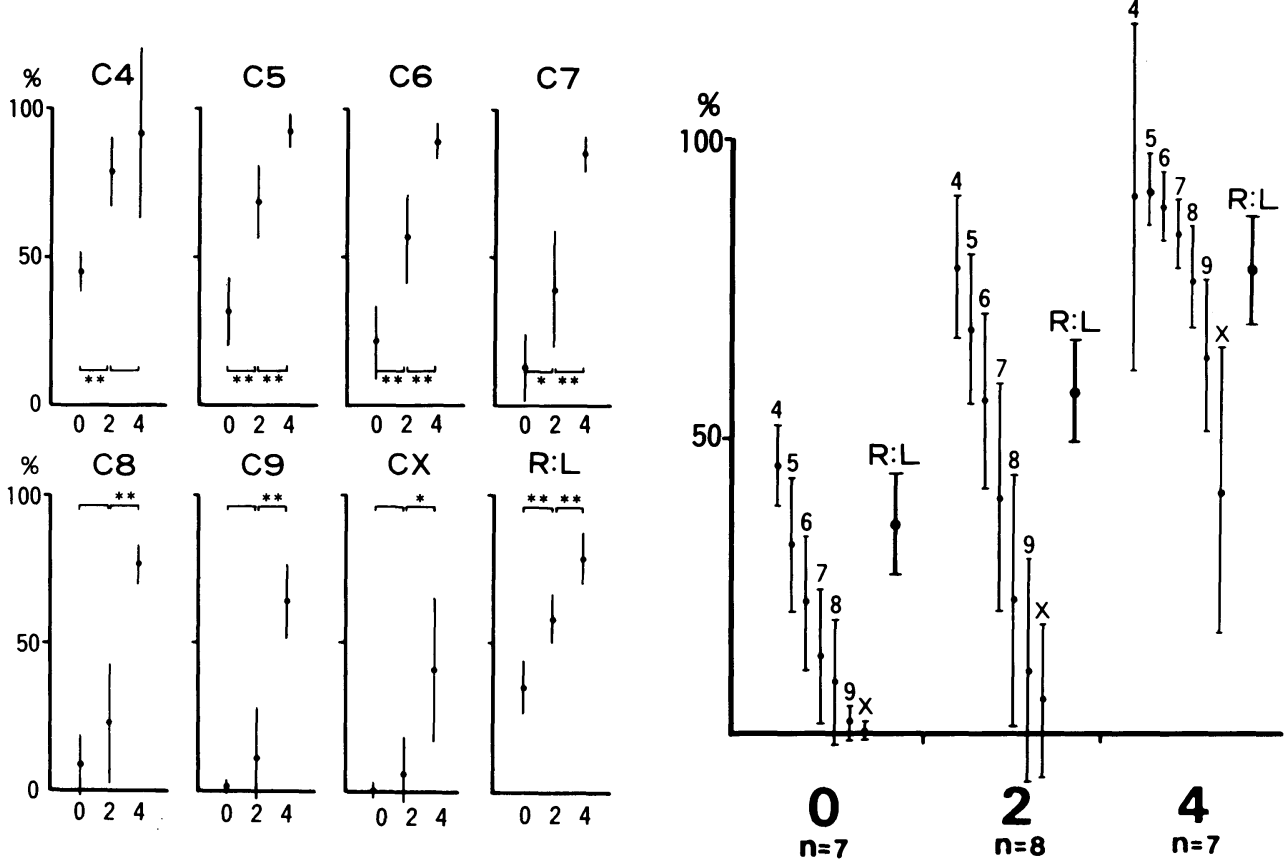

図13 “煩部膨満”症例における表情筋トポグラムの左右差解析と 3 段階 肉眼的麻痺評価法との比較成績 
ってきている．乙のような趨勢の中で，筋電図 などの神経筋生理学的検査に㧈いても同様の画 像解析の必要性が迫られていると言っても過言 ではない。

等電位図（トポグラム）の概念は, 1948年, S. Goldman が心電図の表示を波形そのもので はなく，体表面上の部位別の電位の大きさと時 間的経過といった電位分布の二次元表示を試み た報告 ${ }^{7)}$ 亿始まる．我が国においては，1957 年, 本間 ${ }^{8)}$ が「走査式座標記録 Scanning Coordinate Recorder」として, 腓腹筋の誘 発筋電図におけるM波， $\mathrm{H}$ 波の電位変化ならび に時間的経過を記録機器の関係上一次元的に才 シロスコープ上に示したのを契機とする. 当時 は, 記録機器の性能が十分でなく, 二次元表示 するという目的を満たすレベルにまで達してい なかったため, 精密な生体電位の画像表示を満 足なまでに行なうことはできなかった．1960年 代から1970年代にかけて, 多次元表示に関する 数学的基礎9) が確立されるのと呼応して, コン ピュータを用いた生体計測が飛躍的に進歩し た. 脳波の解析法としてはそれまでに, toposcopic な表現形式の域を出なかったが, 1969 年, Harris $~^{10)} や$ Estrin, Uzgalis ${ }^{11)}$ が発 表した spatio-temporal なEEGの Computer Display System はその後の等電位図 解析の発展に大きく寄与し, 1971年, Leh$\operatorname{mann}^{12)}$ が $48 \mathrm{ch}$ のシステムを用いて脳波に おける $\alpha$ 波の分布を等高線状に示した報告を 初め, 1976年, 上野, 松岡 ${ }^{13)}$ は, 「徐波を示す 異常脳波の抽出とその表示法」と題して, 脳波 活動を等価的電位として捉らえ, 脳波の空間分 布を等高線地図として表現する画像解析法を開 発した。その際, 松岡らは, 補間式を利用し て，10〜20法に基づいた16個の電極間の電位変 化を曲面的に算出する方法を奨入し, 頭皮上の 電位分布を二次元的に表示するととに成功し た.その後, 1978年, Duffy ら ${ }^{14)}$ は E E Gや visual evoked potential $の 24 \mathrm{ch}$, off-line 解析システムを BEAM (Brain Electrical
Activity Mapping）と称して臨床応用例を発 表し, 脳の機能的な生理学的検查法としての等 電位図の重要性を指摘した。耳鼻咽喉科領域に おいては, 1978年, 會田ら ${ }^{15)}$ が松岡らの手法を 聴性脳幹誘発反応に応用している。 また，心電 図に関しても，その on-line 表示における等 電位図の概念を導入した研究が始まり，1982 年, 谷島ら ${ }^{16)}$ は $96 \mathrm{ch}$ のシステムを発表し, 極 めて多いチャンネル記録解析が心電図解析にお いても有用であるととを示した。つまり，体表 面上から記録される電気現象の解析方法として 等電位図（トポグラム）が極めて臨木匛用に即 した表現方法となり得るととが実証されてきた わけである.

顔面神経麻痺の神経生理学的検索において は, 1954年, 時実 ${ }^{17)}$ が正常人の表情運動を安静 時や様々な随意運動時の筋電図解析を詳細に検 討した報告をし，また，同年，早川 ${ }^{18)}$ は顔面神 経麻痺患者の筋電図, 並びに, 誘発筋電図の成 績を発表し, reinnervation voltage の出現 する侍期などにも言及している，その後，誘発 筋電図法はより臨床応用に即した形で発展を続 け，現在では, NET, Neuronography, Blink reflex ${ }^{19)}$ といった検査手法は, 単に病態診断 にとどまらず，予後診断にまで応用されるに至 っている. 一方, 顔面神経麻痖の生理学的検 查法を定量的に表現しょうとする試みは, 森 ら ${ }^{20)}$ の積分モジュール筋電計を用いた方法や八 木ら ${ }^{21)}$ の積分筋電図法, 神崎 ${ }^{22)}$ の筋電図自動 分析法など誘発筋電図や随意収縮時の筋電図解 析において，筋電図そのものというょりは，む しろ, ある特徵のみを抽出または変換して, 表 情筋の特性診断やSynkinesis の早期発見に 有用であるてとが見出されている，表情筋トポ グラムは表情運動全体を一画面上に表示するこ とを目的としており，代表的な表情筋の筋電図 の導出を行った後, 如何なる特徵を抽出すべき かが第一の問題点であった.

開発当初は, プログラムの関係上，得られた 筋電図の最大振幅をむって各 ch の代表値とし 
ていたが，最大振幅が生理学的に有する意義が 不明瞭であり，かつ，プログラム上その再現性 にも問題があった。筋電図を様々な角度から 検討した報告は古くから数多く, 近年では, 1981年, Frederiksen ${ }^{23)}$ が，過去のEMG と force の関係を検討した論文の歴史的考察を行 ない，かつ，彼の成績を総括した論文を発表し ている. その中で, isometric force と筋電図 の様々な factor との相関関係を検討し，上 腕二站筋の表面電極による解析の結果, average amplitude $\_$integrated electrical activity は maximum force の30\%まで直 線的な関係にあり, turns $/ 5 \mathrm{sec}$ 解析が最む force と linear に近い関係にあると報告して いる．神崎らの turns analysis を表情筋に忍 用した成績ではデータに変動が多く瀶床応用に はあまり楜さないとしており，また，顔臬神経 麻舫の回復程度と積分筋電図の関係を検討した 八木らの報告では患者の自覚的回復の程度との 相関が認められるとしている。 てれらの成績を 踏まえて, topography system 700 に求いて 尃用プログラムを開発する際，“表悄筋の筋力 地図”の目的とある程度合致する代表值として 積分筋電図を選定した理由むててにある.

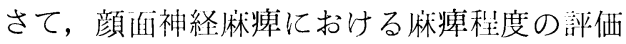
法としては, 肉眼的評価法が最も簡便で, かつ 容永であり，乙れまでに，種々の評価法が捉唱 されている，顔面神経麻痺患者について初心者 と経験者との間に差が生じ難いう法について, 1984年, House ${ }^{24)}$ は Botman and Jongkees, Janssen, Yanagihara, Smith, Adour and Swanson, Stennert らの各評価法について検 討を加え，障害の程度を 6 段階に分類する新し い平価法を提唱している。我が四においては, 1982作の日本顔们神経砄壳会において山内の惏 脾評価法の統一を目指す, シンポジウム ${ }^{25)}$ が開 かれ， 3 段階評価による40点満点法が提唱され ている、いずれにしても，正確な左右差判定を 行なうためには，ある程度の臨休経験を必要と するととは言うまであないが，定量的かつ各観
的な左右判定の娭查法の開発は皆無に近い状 態であった。1985年, Burres ${ }^{26)}$ が “Facial

Biomechanics”之題して表情運動時の皮膚の 動きと integrated EMG（iEMG）の関係を 検討した報告在行なっているが, 皮虚の移動率 と $\log \mathrm{iEMG}$ との間に相関関係が存在するこ とを見出している. この報告の視点もわれわれ が行なってきた表情筋トポグラムと同様の基本 路線（積分筋電図と筋力の関係）を有してい る. トポグラム解析の発達の過程において既に 示した如く, 本法は, 既存の計測法において少 ない電極数で行なっていたものをコンピュータ 一の多チャンネル解析能と自由な画像表示機能 によって，倜々のデータの特徵を全く別の表現 形式をもって表現するため，アナログ的な基本 データとは異質な印象を与えるが，その視認性 に宫む表現才法は表情運動全体を対象として解 析し，提示する手法としては現在のとてろ最良 のものと思われる。しかしながら，その臨床応 用においては，な打解決すべき問題点があるて とは,いうまでもない.

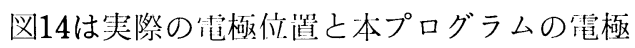
の基本的位狊関係の相逢について示したもので ある.アルゴリズムに扔いて規程している電 極位置は，脳波の10２0法に基づいており，16 ch の基本訖録部位の值から $5 \times 5$ (25筒所) の未䛉録部位 9 筒所の值を平均值で算出し, 乙 れらの值を基本としてC R T 上2500䇢所の值を 補間式によって求め, トポグラムとして再構成 している. この埸合, 各電極間を $5 \mathrm{~cm}$ 間隔に想 定した補間を行なっており，図14に示した如 く，顔面皮虐上に贴付した電極位置とは異なる 配置となっている。つまり, 表情筋トポグラム の埸会，脳波に打ける電極位䈯よりも主に左右 う们において維小した笔極位㯰にあり，尖際の 他極位滥より C R T 上の位置がより抎大した部 位となっているため, 表示結果が左右力问を中 心に拡大したものになる．乙の電極位㯰の相違 に起因する整害としては, 実際の表情遇動と卜 ポグラム表示結果に多少のずれのみられる可能 
性があることである．実際の症例での表示結果 では, 図4, 図5, 図6, 図 7 において示した 如く, 表示結果と実際の表情運動の間には大き な相違は認められず, 今後, 検討すべき課題で はあるが，現行のシステムにおいても臨床評価 は十分に可能であると思われた。

積分筋電図から得られたデータをどのように 画像に反映させるかも重要な問題の一つであ る. トポグラム解析において最も重要な因子は その画像構成を決定する step 設定であろう.

これまで述べてきたように，表情筋トポグラム は寒色系から暖色系へと11段階でカラ一画像表 示を行なっている. 11段階のカラー表示の中で 最も我々の視覚に訴える色は言うまでもなく赤 色（CX）である．乙の赤色の面積によって筋 放電の活発さが極めて強調されて表示される.

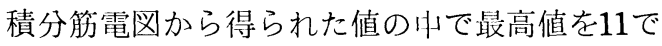
割って 1 step を設定するならば，赤色，すな わち，最高值を意味することになり，ある現象 の focus を視覚に訴えることによってその役 割を果たすととになる。しかしながら，表情筋 トポグラムにおいて最高值にのみ捉れて, 単に 最高值を11で割る step 設定を行った埸合，左 右差解析をするというもう一つの目的とは異な った結果となることが少なくない，図15は右べ ル麻舫患者 (不全麻瘏例) の “強い閉眼” 記錄

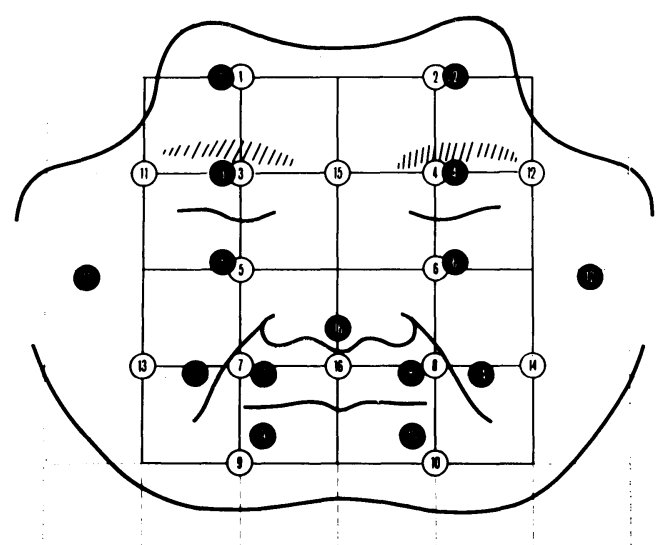

図14 実際の電極配置 $(\bigcirc)$ と画面上の電極配置 $(O)$
例であるが，同一の $\mathrm{EMG}$ 記録に対して二つの 異なる step 設定にて表情筋卜ポグラムを作成 して示したものである。段は，健常側で最高 值を示した左上眼瞼部の值を11で割った step 設定を行なったもの（第一法）であり，下段は 健常側で 2 番目の值を示した左下眼瞼部の值を 11で割ってトポグラム表示を行なったもの（第 二法）で沾る．第一法で作成したトポグラムに おいては左上眼瞼部が最も濃いパターンで示さ れ，ての部位が強い閉眼を行なった際の最高活 動部位であることを表している．第二法で作成 した下段のトポグラムにおいては左眼輪筋部全
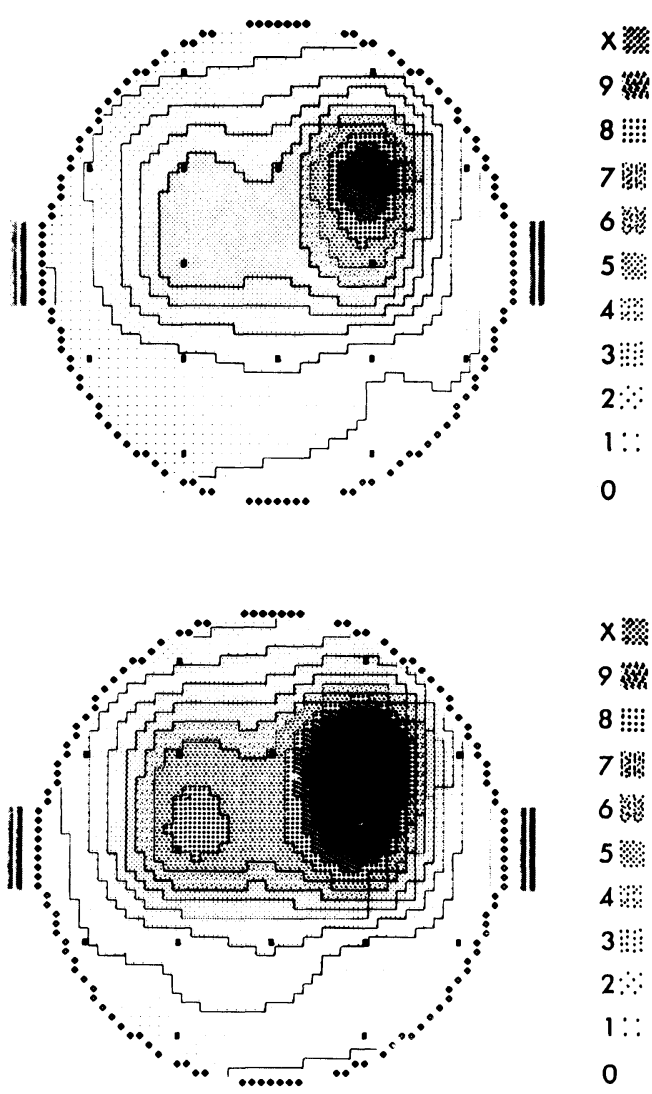

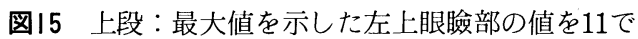
割って作成した表情筋トポグラム。

下段：健側部で 2 番目の值を示した左下眼瞼 部の值を11で割って作成した表情筋トポグラ $\Delta$. 
体が濃いパターンで表示され，トポグラム全体 から受ける印象として，磨㯅側との対比がより 明確に示された表示結果となっている，表情運 動の左右差を検討しない場合（重症筋無力症や 顔面痤攣など）は，第一法によって step 設定 を行ない，表情運動に端的に表れる特徽を検討 すべきは論を待たない.しかし, 最高値がその 表情運動の第一義的特徴ではない現象, 即ち, 一一側性顔面神経麻痖の如き表情運動の左右差を 検討する場合は, 第一法で表示すると, 健常側 内の focus を強調した表示となり, 加えて,

1 step の值が大きくなるために麻瘏側の小さ な変化については画面上に表現しきれない結果 となる，つまり，健常側の特徵的活動部位全体 を強調しながら，その部位と対称的に表示され る麻舫側の細かい変化まで描出し得る第二法 の方が, 得られた情報の特徵をより生かした step 設定であると言える. 従って, 今回の左 右差判定のために検討した症例は全例第二法に よって step 設定を行ない解析した.

表情筋トポグラムにおいては表情連動の左右 差解析を R/R + L の面積比にて折机線グラフ 表示する方法之, 全体の面積に占める左右のパ 一セント表示を数值表によって示す方法のふた つを採用している. 左右の泊積比を解析の基本 值とした理由は，トポグラムが視梕性に基づく 表現形式であり，トポグラム自体が与える印象 そのあのを左右差判定に反映した解析法が重要 であろうと判断したためである。専用プログ ラム作成前の段階では, 11 class のいずれの class が, または, 他の如何なるパラメーター が実際の麻瘏程度と相関関係を示しているかに ついて想定することは困難であった，臨床応用 に即した表示法へと発展させるためには，ある まとまった瀶床例を解所し，琴段階のシステム の有用性を検討した後に改良点を㒻出すべきは 言うまでもない。本論文においては, 一側性顔

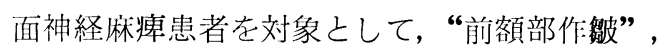

“強い閉眼”，“「ウー」の表情”，“煩部膨 満”の四つの基本的な表情拳動時の表情筋トポ
グラム解析結果と 0 点, 2 点, 4 点の 3 段階に よる肉眼的林盘評価法との関係を検討した。

肉眼的評価法によって分類した 0 点群， 2 点 群, 4 点群の 3 群間に, “前額部作皱”におけ る成績では, C 4, C 5, C 6, の各 class が 1 家の危険率で有意差を示した。 “強い閉眼” 症 例では，C 7,C 8 が，“「ウー」の表情”にお いては, C 4 のみが, また, “煩部膨洅” に関 しては，C 4, C 5, C 6 の class がそれぞれ 肉眼的評㑛法とある程度一致した面積比を示す ことが判明した。また，てれら 4 基本表情すべ てに扣いて，左右の積分 $\mathrm{EMG}$ 值から算出した $\mathrm{R}$ ：Lが $1 \%$ の高い危険率で 3 群間に有意の差 が認められた。左右の積分 $\mathrm{EMG}$ 值の比が有意 差:を示した成績は，表情筋トポグラムの基本值 として積分筋電図を選んだ根拠と合致するもの であるととを立証している，各表情運動におい て，有意着を示した class が異なる結果とな ったが，個々の表情筋の特性や電極配置の在り 方, また, 電極位置によっては補間によって決 定される面積值に変動が生じ得る事など様々な 要因によって各々の表情運動の表示結果に影響 を与えているてとを示したもので当然の結果で あると考えられる．全体的な傾向としては．

“前額部作睎”において，各 class 間の変動 が著明に現われ，本表情運動のトポグラム解析 の中心的電極の数が二筒所である火点を示した 結果と考えられた。 “強い閉眼”, “「ウー」の 表情”，“煩部膨満”の表情運動の成績では個 々の class の槛準偏差がやや幅広い值を示し たむのの, 一定の間隔で各 class の平均值が 推移していることが示され，乙れらの表情運動 に扔いては安定した記録が得られているてとが 示唆された。また， 口輪筋部の運動においては 0 点時においても CXの段階まで炑猈側に出現 しているが，乙れは，画村 ${ }^{27)}$ が指摘している如 く， 口輪筋の交叉性支配が及んでいるととを示 す実例と考えられた。いずれにしても，本表情 筋トポグラフィーシステムは, 顔面の動作や病 態をかなり忠実に再構成し, かつ, 理解しやす 
い画像表示法として解析できるので，新しい臨 床診断の一手法として極めて有用であることは 疑いない，今後，さらに症例を重ねて検討する とともに, 器械やプログラムの改良を通じて, より簡便で，無侵襲，そして再現性に富む客観 的な診断手法の確立を目指して研究すべきは論 をまたない。

\section{結語}

様々な生理学的検查がトポグラム的表示法を 導入している今日, 極めて多数の筋肉の協同運 動である表情運動の解析に等電位図の概念を応 用することは時代的な流れとも言える．著者 は, 積分筋電図を基本とした表情筋卜ポグラム を開発し，表情運動の解析を行なった。その結 果, 表情運動のトポグラム解析が実際の表情の 特徽をよく反映した表示法であり, 顔面神経麻 瘏症例においても，本法が再現性に優れ，その 左右差判定にも客観的定量的評価法として有用 であることが判明した．今後，電極配置の改 良, 新しい補間関数の検傠など課題が残されて いるが，臨床例を重ねることによって本法が真 に“表情筋筋力地図”之も言える画像表示へ一 歩でも近づいていくことが大いに期待される.

稿を終えるにあたり，本研究に対し御懇切なる御 指導と御鞭撻を賜った鹿児島大学耳鼻咽喉科学教室 大山＼cjkstart勝教授に深甚なる感謝の意を表します．また， 本研究を支援して下さった日本電気三栄社に対し心か ら感謝致します。

\section{参考文献}

1）小幡悦朗，大堀八洲一，清田隆二：表情運動の力 ラー画像表示の試み. Facial N Res Jpn 2 : $59 \sim 62,1982$.

2 ) 小幡悦朗, 山野 隆, 宇宿功一郎, 他: 重症筋無 力症患者の表情筋 EMG Topogram一 テンシロ ンテストへの応用成績一. Facial N Res Jpn $3: 17 \sim 20,1983$.

3 ）古田 茂, 他：顔面神経麻癘陳旧例に対する形成 外科療法の経験. Facial N Res Jpn 3:191 〜194, 1983.
4 ）小幡悦朗, 大山 勝, 古田 茂：表情運動のカラ 一画像表示. 生体等電位図一基礎 と 現況一. 139 〜144頁, にゅーろん社, 1984.

5 ）大山 勝, 小幡悦朗：表情筋のカラートポグラム 解析について. 耳鼻臨床 $78: 22 \sim 23,1985$.

6 ) Ohyama M, Obata E and Furuta S: Color electromyographic topographic analysis of facial movements. Am J Otolaryngol 6 : 185 190, 1985 .

7 ) Goldman S, Vivian WE, Chien CK, et al : Electrical mapping of the activity of the heart and the brain. Science 108:720 $723,1948$.

8 ) 本間三郎, 渡辺士郎：走查式座標記録器 Scanning Coordinate Recorer について. 低周波医 学 1:1 4, 1957.

9 ) 宮川洋：多次元空間中の定常的確率变数の標 本化定理. 電気通信学会雑誌 $42: 421 \sim 427$, 1959.

10) Harris JA, Gordon MM Reginald G, et al : Computer-controlled multidimensional display device for investigation and modeling of physiologic systems. Comp Biomed Res 2 : 519 535, 1969.

11) Estrin $T$ and Uzgalis $R$ : Computer display of spatio-temporal EEG patterns. IEEE Trans Biomed Eng 16:192 196, 1969.

12) Lehmann D : Multichannel topography of human alpha EEG fields. Electroenceph Clin Neurophysiol 31:439〜449, 1971.

13）上野照剛，松岡成明：徐波をしめす異常脳波の抽 出とその表示法. 医用電子と生体工学 14:118 $\sim 124,1976$.

14) Duffy FH Burchfiel JL and Lombroso CT: Brain electrical activity mapping (BEAM): A method for extending the clinical utility of EEG and evoked potential data. Ann Neurology $5: 309 \sim 321,1979$.

15）曽田豊二, 加藤寿彦, 調 重昭, 他：聴性誘発反 応のトポグラフィーについて. 耳鼻 24:571〜 $583,1978$.

16）谷島一嘉, 木下重博, 田中 博, 他：動画像表示 機能を持った体表面電位分布測定表示システムの 
開発. 医用電子と生体工学 $20: 321 \sim 325,1982$.

17）時丰 博：顔面筋の筋電図学的研究. お茶の水医 学雑誌 $2: 1 \sim 14,1954$.

18）早川 宏：顔面神経麻痺の臨床的研究（殊にその 筋電図学的所見について). 東京医学雑誌 62 ： $214 \sim 233,1954$.

19）森川謙三：踩目反射に関する臨床的研究. 耳鼻 25 : 補 $5 ; 707 \sim 716,1977$.

20）森弘, 北原一明, 北 真行, 他：末梢性顔面 神経麻焷の回復過程における病的共同運動の測定 一筋電図の積分モジュールによる分析一. 耳鼻臨 休 $72: 957 \sim 964,1979$.

21）八木伸也，石川保之：末梢性顔面神経麻瘏と積分 筋電図. 耳鼻臨床 $73: 1355 \sim 1361 ， 1980$ 。

22）神崎 仁, 大内利昭, 石原伝幸：末梢性顔面神経 麻痺に対する筋電図自動分析法の検討. 耳展 19:191〜194, 1976.

23) Frederiksen AF : Electrical activity and for - ce during voluntary contraction of normal and diseased muscle. Acta Neurol 63 : Suppl $83 ; 1 \sim 60,1981$.

24) House JW : Facial nerve grading systems. Laryngoscope $93: 1056 \sim 1069,1983$.

25）柳原尚明, 細見英男, 山本悦生, 他：顔面麻瘏 の程度の評価基準とその根拠（有用性を含む). Facial N Res Jpn $2: 1 \sim 11,1982$.

26) Burres SA : Facial biomechanics ; The standards of normal. Laryngoscope 95:708 $714,1985$.

27）西村宏子：顔面表情筋の神経支配に関する誘発筋 電図学的研究 (前編). 耳鼻臨床 $69: 453 \sim 464$, 1976.

$$
\left(\begin{array}{l}
\text { 原稿採択：昭和 } 62 \text { 年 } 10 \text { 月 } 2 \text { 日 } \\
\text { 別刷請求先：小幡悦朗 } \\
\text { 个 } 890 \text { 鹿児島市宇宿町 } 1208-1 \\
\text { 鹿児島大学医学部耳鼻咽喉科教室. }
\end{array}\right)
$$

